\title{
Behaviour of different bare and anodised aluminium alloys in the atmosphere
}

\author{
M $^{\mathrm{a}}$.J. Bartolomé ${ }^{\mathrm{a}}$, J.F. del Río ${ }^{\mathrm{b}}$, E. Escudero ${ }^{\mathrm{a}, *}$, S. Feliu Jr. ${ }^{\mathrm{a}}$, \\ V. López ${ }^{\text {a }}$, E. Otero ${ }^{\text {a }}$, J.A. González ${ }^{\text {a }}$ \\ a National Centre for Metallurgical Research (CENIM), Spanish National Research Council (CSIC), Avda. Gregorio del Amo, No. 8, 28040 Madrid, Spain \\ ${ }^{\mathrm{b}}$ Alcoa Europe, Avda. de Elche, No. 109, 03008 Alicante, Spain
}

Received 30 May 2007; accepted in revised form 11 October 2007

Available online 25 October 2007

\begin{abstract}
Exposure tests in natural atmospheres are an indispensable means for determining the behaviour and durability of metallic materials in the atmosphere. The corrosion behaviour of bare aluminium and anodised aluminium with three different coating thicknesses has been evaluated for two years' exposure in two natural atmospheres of very different corrosivities: one urban and the other marine. Several techniques have been used to evaluate changes in the specimens during exposure, but special attention is paid to the direct measurement of corrosion by gravimetry and its indirect estimation by the comparatively much more sensitive electrochemical impedance spectroscopy (EIS) technique. The results show that if no demands are placed on the conservation of its appearance, aluminium may be used without protection even in atmospheres of medium or high corrosivity. The anodising and sealing of aluminium alloys, above an ill-defined minimum thickness threshold, is an appropriate solution to prevent localised corrosion of aluminium and to conserve its appearance, even in aggressive atmospheres.
\end{abstract}

(C) 2007 Published by Elsevier B.V.

Keywords: Aluminium alloys; Anodizing; Sealing; Atmospheric corrosion; Durability

\section{Introduction}

Of all the very electronegative metals, only $\mathrm{Cr}$ and $\mathrm{Al}$ have a Pilling and Bedworth ratio of $>1$ [1]. Their high affinity for oxygen enables them to develop oxide films at room temperature, and due to the favourable relationship between the specific volumes of the oxide and the metal, 1.28 in the case of aluminium, these films possess excellent adhesion, continuity and corrosion resistance properties. This explains why aluminium and its alloys have been accredited as industrial materials of very high durability, despite their position in the electrochemical series, with potentials of close to $-1700 \mathrm{mV}_{\mathrm{H}}$.

When new aluminium surfaces are exposure to the air an extremely thin protective oxide film, around $25 \AA$ thick [2], is thus formed. Although it has not been proved, this oxide layer is believed to exist in several grades of hydration $\left(\mathrm{Al}_{2} \mathrm{O}_{3} \cdot x \mathrm{H}_{2} \mathrm{O}\right)$ depending on the exposure conditions, especially relative humidity and temperature. In natural environments the normal

\footnotetext{
* Corresponding author. Tel.: +34 91 5538900; fax: +34 915347425.

E-mail address: mebaquero@cenim.csic.es (E. Escudero).
}

corrosion reaction implies combination with water to form aluminium hydroxide and hydrogen [2]:

$2 \mathrm{Al}+6 \mathrm{H}_{2} \mathrm{O} \rightarrow 2 \mathrm{Al}(\mathrm{OH})_{3}+3 \mathrm{H}_{2} \uparrow$

constituting, even without the concurrence of free oxygen, a film that is so corrosion resistant that it guarantees the behaviour of aluminium alloys as passive materials in natural environments: atmosphere, fresh water, seawater and soils.

Consequently, if there are no demands regarding the conservation of their appearance, aluminium alloys may be used in the atmosphere without protection for very long time periods; this being the environment where an estimated 60-70\% of all aluminium structures are exposed [3]. Notable cases such as the roofs of the Church of St Gioacchino (1897) and the Israeli Temple (1903), both in Rome [4], which presented minimal damage with pitting depths of less than $0.1 \mathrm{~mm}$ in inspections performed in the 1950s [5], are the best demonstration of the excellent resistance of these materials in natural environments.

When corrosion occurs - in the presence of certain pollutants it is localised: pitting corrosion, intergranular corrosion, stress cracking corrosion or exfoliation; with pitting corrosion being by far the most frequent. The risk of localised corrosion of aluminium 
and its alloys is essentially combated, in the case of atmospheric exposure, by means of anodising and lacquering. The following analysis considers only the first option, based on the supposition that, according to some authors [6-9], the time required to produce a predetermined degree of deterioration in atmospheric exposure (the logarithm of the time, according to others [10]) is proportional to the thickness of the coating.

All previous studies carried out at CENIM in relation with the anodising and sealing of aluminium have used as the base material an aluminium of commercial purity, alloy 1050, with at least $99.5 \%$ aluminium purity. Based essentially on EIS and transmission electron microscopy, research has been performed on traditional hydrothermal sealing (HTS) [11-18], cold sealing $[19,20]$, and the changes experienced by anodic coatings during ageing; a process that remains active for many years [15-24].

The aim of the present work is to determine the characteristics of anodic films formed on substantially different aluminium alloys, with the purpose of establishing as far as the acquired knowledge with aluminium of commercial purity have wide validity and may be extended to other aluminium alloys. An analysis is made of the behaviour of different materials, in bare state and with three anodic film thicknesses, covering the range used in architectural applications, exposed for two years at two natural test sites in atmospheres of very different corrosivities, located in the University district of Madrid (urban atmosphere) and approximately $100 \mathrm{~m}$ from the sea shore at Alicante. Although different techniques have been used, including X-ray photoelectron spectroscopy (XPS), optical microscopy and scanning and transmission electron microscopy (SEM and TEM), the present communication pays special attention to the direct measurement of corrosion by gravimetry and its indirect estimation by EIS, of comparatively very high sensitivity.

\section{Experimental procedure}

\subsection{Aluminum alloys}

The tested aluminium alloys were 1050, 2017-T4 of Al-4\% $\mathrm{Cu}, 5754-\mathrm{H} 111$ of Al- $2.90 \% \mathrm{Mg}$, and $6082-\mathrm{T} 6$ of $\mathrm{Al}-0.88 \% \mathrm{Si}-$ $0.80 \% \mathrm{Mg}$, whose compositions are detailed in Table 1 (mass percentages). The $\mathrm{T} 4$ state refers to a solution heat treatment followed by natural ageing; T6 refers to solution treating and artificial ageing; and $\mathrm{H} 111$ refers to annealing, in all cases with holding stages at temperatures in excess of $300{ }^{\circ} \mathrm{C}$.

\subsection{Anodising of specimens}

$100 \times 50 \times 1.5 \mathrm{~mm}$ specimens were degreased by submerging for $5 \mathrm{~min}$ in an aqueous solution of phosphoric and chromic acids at

Table 1

Chemical composition of aluminium alloys (mass percentages)

\begin{tabular}{lllllllll}
\hline Sample & $\mathrm{Si}$ & $\mathrm{Fe}$ & $\mathrm{Cu}$ & $\mathrm{Mn}$ & $\mathrm{Mg}$ & $\mathrm{Cr}$ & $\mathrm{Zn}$ & $\mathrm{Ti}$ \\
\hline Pure Al & 0.080 & 0.290 & 0.003 & 0.003 & 0.006 & - & 0.040 & 0.012 \\
$\mathrm{Al}-\mathrm{Cu}$ & 0.370 & 0.340 & 4.040 & 0.630 & 0.600 & 0.010 & 0.050 & 0.050 \\
$\mathrm{Al}-\mathrm{Mg}$ & 0.090 & 0.260 & 0.001 & 0.110 & 2.900 & - & 0.022 & 0.004 \\
$\mathrm{Al}-\mathrm{Si}-\mathrm{Mg}$ & 0.880 & 0.360 & 0.040 & 0.470 & 0.800 & 0.003 & 0.040 & 0.060 \\
\hline
\end{tabular}

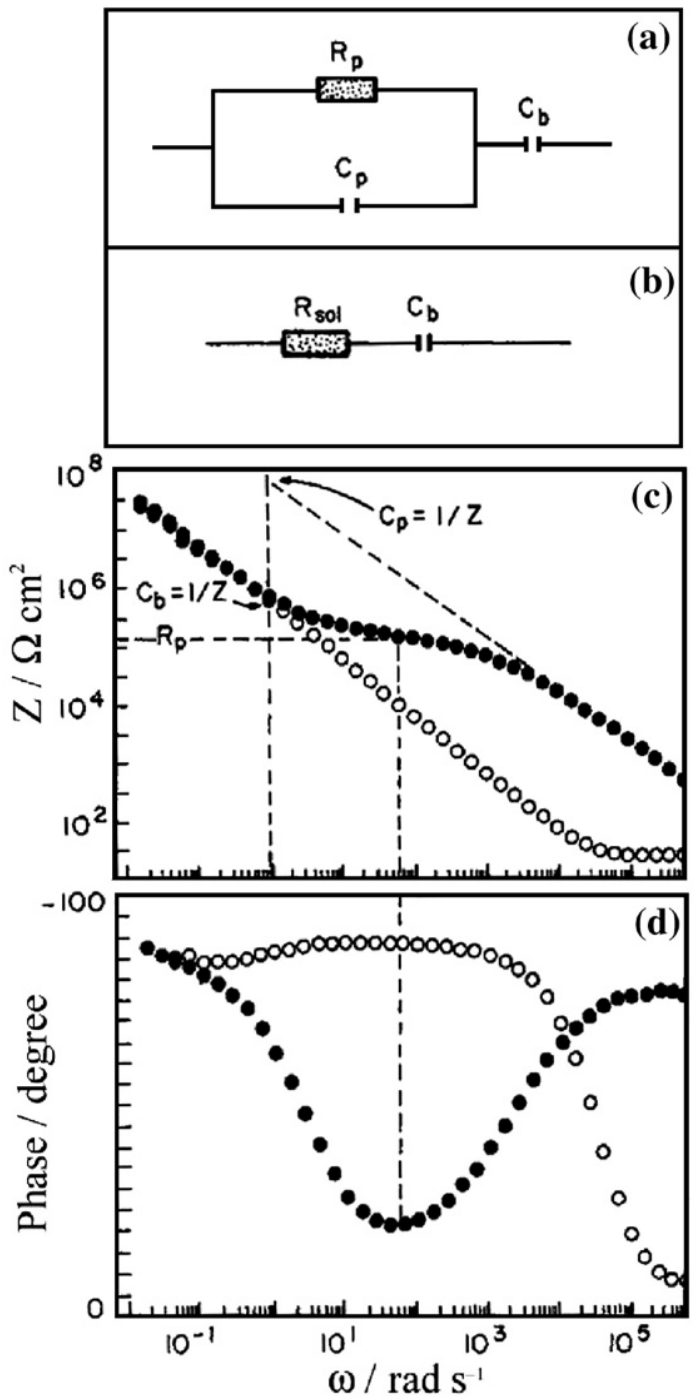

Fig. 1. Simplified equivalent circuits for anodic films, sealed (a) and unsealed (b), and typical impedance diagrams of a correctly sealed $(\bullet)$ and unsealed $(\bigcirc)$ anodic film (c and d).

concentrations of approximately 250 and $55 \mathrm{~g} / \mathrm{L}$ at a temperature of $30-40{ }^{\circ} \mathrm{C}$. They were then etched in a $100 \mathrm{~g} / \mathrm{L}$ sodium hydroxide aqueous solution at $40-50{ }^{\circ} \mathrm{C}$ for $50-60 \mathrm{~s}$ and neutralised by immersion for a few seconds in the same solution used for degreasing. After each treatment the specimens were repeatedly rinsed with distilled water and dried with compressed air.

Anodic coatings were generated on specimens of the various alloys by submerging in a $180 \mathrm{~g} / \mathrm{L} \mathrm{H}_{2} \mathrm{SO}_{4}$ aqueous solution at $20{ }^{\circ} \mathrm{C}$, stirred with compressed air, through which a current density of $1.5 \mathrm{~A} / \mathrm{dm}^{2}$ was passed. Anodising times were variable

Table 2

Atomic percentages observed by XPS on the outer surface of the alloys after etching prior to anodising and after $10 \mathrm{~min}$ of $\mathrm{Ar}$ ion bombardment

\begin{tabular}{llllll}
\hline Sample & $\% \mathrm{O}$ & $\% \mathrm{Al}$ & $\% \mathrm{Mg}$ & $\% \mathrm{Cu}$ & $\mathrm{O} / \mathrm{Al}$ \\
\hline Pure Al & 60 & 40 & $\leq 0.1$ & $\leq 0.1$ & 1.5 \\
$\mathrm{Al}-\mathrm{Cu}$ & 60 & 39 & $\leq 0.1$ & 1 & 1.54 \\
$\mathrm{Al}-\mathrm{Mg}$ & 60 & 40 & $\leq 0.1$ & $\leq 0.1$ & 1.5 \\
$\mathrm{Al}-\mathrm{Si}-\mathrm{Mg}$ & 61 & 39 & $\leq 0.1$ & $\leq 0.1$ & 1.56 \\
\hline
\end{tabular}


Table 3

Atomic percentages observed by XPS on the outer surface of the alloys after the anodising operation

\begin{tabular}{llllll}
\hline Sample & $\% \mathrm{O}$ & $\% \mathrm{Al}$ & $\% \mathrm{~S}$ & $\mathrm{O} / \mathrm{Al}$ & Most likely compound \\
\hline Pure Al & 66 & 32 & 2 & 2.1 & $\mathrm{AlOOH}$ \\
$\mathrm{Al}-\mathrm{Cu}$ & 66 & 32 & 2 & 2.1 & $\mathrm{AlOOH}$ \\
$\mathrm{Al}-\mathrm{Mg}$ & 64 & 34 & 2 & 1.9 & $\mathrm{AlOOH}$ \\
$\mathrm{Al}-\mathrm{Si}-\mathrm{Mg}$ & 64 & 33 & 3 & 1.9 & $\mathrm{AlOOH}$ \\
\hline
\end{tabular}

to produce coatings of approximately 7,17 and $27 \mu \mathrm{m}$. HTS in deionised water at boiling point for $60 \mathrm{~min}$ was applied to a part of specimens; this being sufficient time to achieve the sealing quality indices demanded by industry, even on the thickest coatings.

\subsection{Atmospheric exposure tests and gravimetric determinations}

Two sets of specimens of the alloys in bare condition and anodised with the three above-mentioned coating thicknesses, sealed and unsealed, were exposed in June 2004 at an angle of $45^{\circ}$ in standard racks installed on the CENIM roof terrace in the University district of Madrid and in installations that belong to the company Alcoa situated $100 \mathrm{~m}$ from the sea shore at Alicante. The corrosivity categories of the Madrid and Alicante stations, estimated according ISO standard 9223 [25], are C2 and $\mathrm{C} 4$, respectively.

In order to know the efficiency of the anodising operation, the porosity of the coatings obtained, their reactivity in the anodising bath, and even in the etching bath prior to anodising, weighing was performed after etching prior to anodising (P1), after the anodising of the specimens (P2), after prolonged sealing to completely saturate the pores (P3), and after removal of the oxide layer in a boiling phosphoric-chromic mixture [26] (P4). The specimens exposed to the atmosphere were controlled after 6, 12 and 24 months (P5).

Subtracting P2-P1 yields the amount of oxide formed during anodising; subtracting P4-P1 gives the amount of aluminium consumed to form the oxide; and the quotient between these two amounts, P2-P1/P4-P1, provides an estimate of the efficiency of the anodising process known as the coating ratio, $R$. P3-P2 determines the mass gain during sealing and allows an evaluation of the coating porosity, provided the coating thickness is known and it is accepted that the pores have been saturated with water. The thickness of the oxide layers was checked using a commercial instrument supplied by Elcometer Instrument Ltd., employing the

Table 4

Different anodic layer parameters obtained by interpolation of the results for layers of $20 \mu \mathrm{m}$ thickness

\begin{tabular}{|c|c|c|c|c|c|c|c|}
\hline \multirow[t]{2}{*}{ Alloy } & \multirow{2}{*}{$\begin{array}{l}\text { Thickness } \\
\mu \mathrm{m}\end{array}$} & \multirow{2}{*}{$\begin{array}{l}\Delta \mathrm{m} \\
\frac{\mathrm{NaOH}}{\mathrm{mg}} \\
(5 \mathrm{~min})\end{array}$} & \multirow{2}{*}{$\begin{array}{l}\Delta \mathrm{m} \\
\text { anodising } \\
\mathrm{mg}\end{array}$} & \multirow{2}{*}{$\begin{array}{l}\text { Porosity } \\
\overline{\%}\end{array}$} & \multirow{2}{*}{$\begin{array}{l}\frac{\Delta \mathrm{m}}{\text { sealing }} \\
\mathrm{mg}\end{array}$} & \multirow{2}{*}{$\begin{array}{l}\frac{\Delta \mathrm{m}}{\mathrm{H}_{2} \mathrm{SO}_{4}} \\
\mathrm{mg}\end{array}$} & \multirow{2}{*}{$\frac{\begin{array}{l}\text { Coating } \\
\text { ratio }\end{array}}{R}$} \\
\hline & & & & & & & \\
\hline Pure Al & 2.2 & -140 & 120 & 15 & 35 & -50 & 1.39 \\
\hline $\mathrm{Al}-\mathrm{Si}-\mathrm{Mg}$ & $\lg 2.3$ & -146 & 150 & 13 & 29 & -75 & 1.42 \\
\hline $\mathrm{Al}-\mathrm{Mg}$ & 3.0 & -205 & 100 & 25 & 50 & -190 & 1.20 \\
\hline $\mathrm{Al}-\mathrm{Cu}$ & 3.8 & -224 & -190 & 40 & 68 & -230 & 0.74 \\
\hline
\end{tabular}

$\Delta \mathrm{m}=$ mass increase in the different treatments.

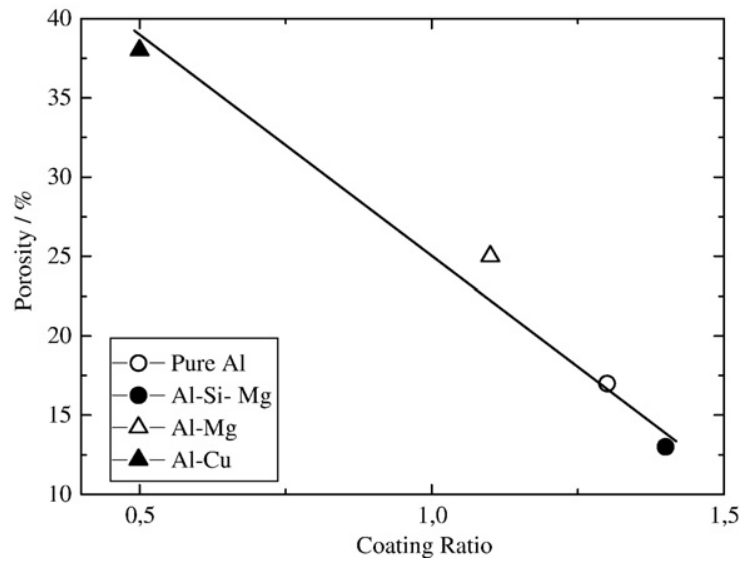

Fig. 2. Effect of anodic film porosity on the coating ratio.

eddy-current principle (induced currents). The reactivity of coating in the anodic bath was estimated by exposure of the unsealed anodic layer of medium thickness to anodising solution $(180 \mathrm{~g} / \mathrm{L}$ $\mathrm{H}_{2} \mathrm{SO}_{4}$ ) during $1 \mathrm{~h}$, without applied current. Endlich, P5-P3 and $\mathrm{P} 5-\mathrm{P} 2$ represent the mass changes due to the atmospheric exposure of sealed and unsealed specimens, respectively.

\subsection{XPS technique}

For the performance of surface analysis of the studied specimens, use was made of a VG Microtech spectrometer, model MT500, and an X-ray source equipped with a magnesium anode (radiation energy $\mathrm{K} \alpha=1253.6 \mathrm{eV}$ ), operating at a voltage of $15 \mathrm{keV}$ and an emission current of $0.020 \mathrm{~A}(300 \mathrm{~W})$. The operating procedure and the conditions maintained during the tests have been described in detail elsewhere $[27,28]$.

\subsection{Characterisation of anodic layers by EIS}

AC impedance measurements were carried out in unstirred aerated $3.5 \%(\mathrm{w} / \mathrm{w})$ potasium sulphate solution at $25 \pm 1{ }^{\circ} \mathrm{C}$. Impedance diagrams were recorded for the sealed and unsealed anodised specimens, immediately after anodising and sealing and after different ageing times. A surface area of $1 \mathrm{~cm}^{2}$ was

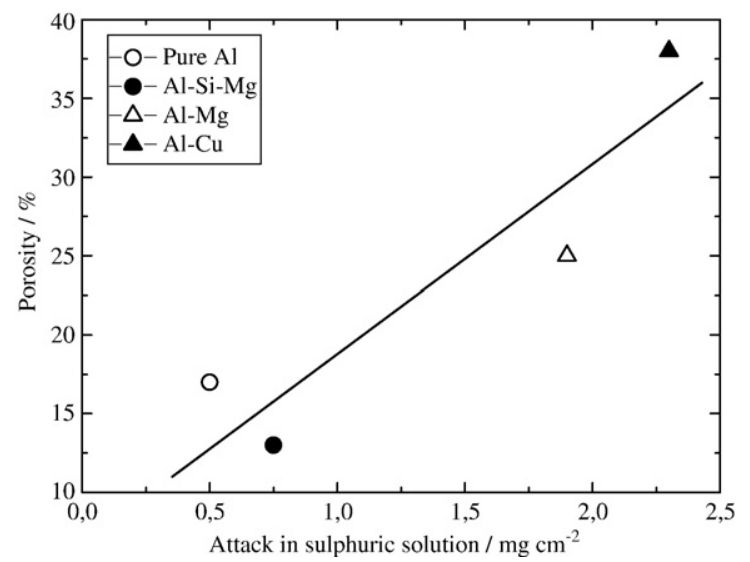

Fig. 3. Porosity versus attack in the anodising bath sulphuric solution $(1 \mathrm{~h}$ without passage of current). 
(a)
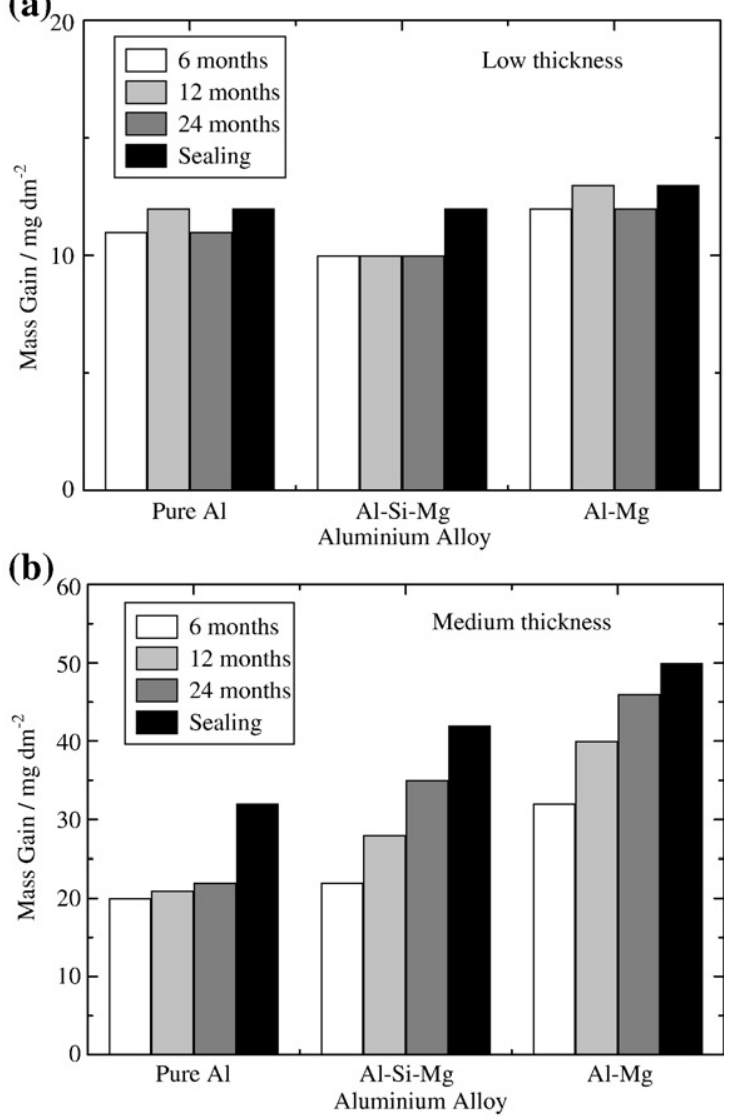

(c)

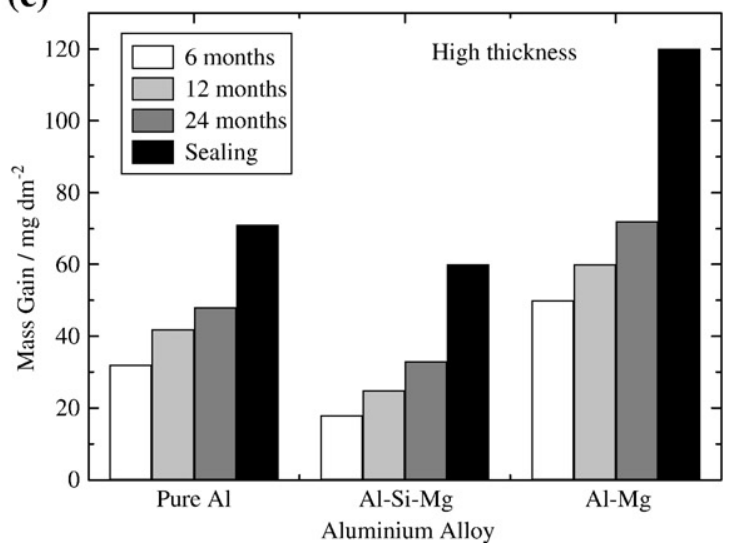

Fig. 4. Mass gains verified during the course of exposure to the Alicante atmosphere of unsealed anodic films of low (a), medium (b) and high (c) thickness developed on the different considered aluminium alloys.

exposed to the impedance test solution, applying a $10 \mathrm{mV}$ amplitude sine wave and a frequency range from $1 \mathrm{mHz}$ to $100 \mathrm{kHz}$, using the same equipment and test cell as previously reported $[13,15]$.

Fig. 1 shows the typical impedance diagrams of an anodic film in unsealed state and another after $45 \mathrm{~min}$ of traditional hydrothermal sealing $(2.5 \mathrm{~min} / \mu \mathrm{m}$ of thickness $)$ in boiling deionised water. It can be seen that over a wide frequency range the impedance of the sealed and unsealed anodic films differs by 2-3 orders of magnitude, making EIS a very sensitive tool to discern sealing quality or to detect changes in the characteristics of the barrier and porous layers. This figure also shows in schematic form how the capacitance of the barrier and porous layers, $C_{\mathrm{b}}$ and $C_{\mathrm{p}}$, can be estimated by extrapolation of the straight line regions to the angular frequency $\omega=1$, and how the porous layer resistance, $R_{\mathrm{p}}$, can be estimated from the impedance value corresponding to the minimum phase angle $\theta$ [13]. Different equivalent circuits have been proposed to simulate the behaviour of anodised aluminium [13,29-31]. The very simple circuits initially proposed by Hitzing and Juttner for sealed and unsealed anodic films and reproduced in Fig. 1a and $\mathrm{b}$, respectively, yield sufficiently approximate responses for most practical applications, and are taken as the essential basis for the estimates made in the present research. $R_{\mathrm{p}}$ and $R_{\mathrm{b}}$ are the resistances of the porous and barrier layer, $C_{\mathrm{p}}$ and $C_{\mathrm{b}}$ the associated capacitances, and $R_{\text {sol }}$ the electrolyte resistance

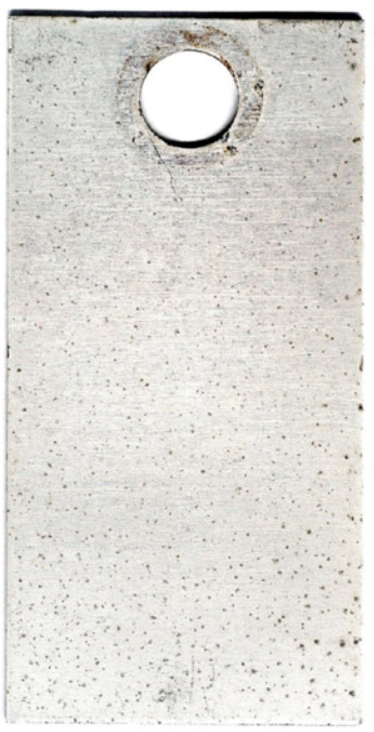

Pure Al

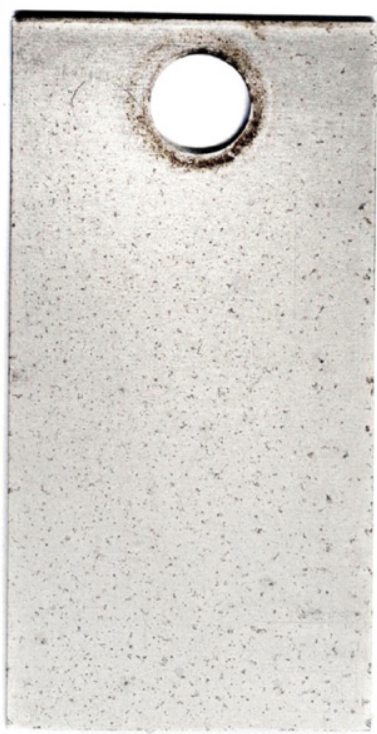

Al-Si-Mg

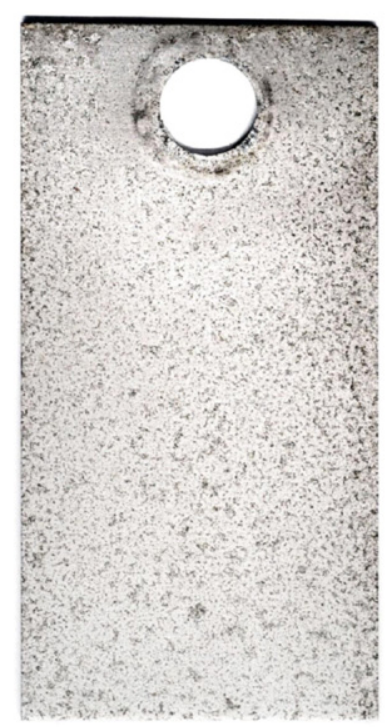

Al-Cu

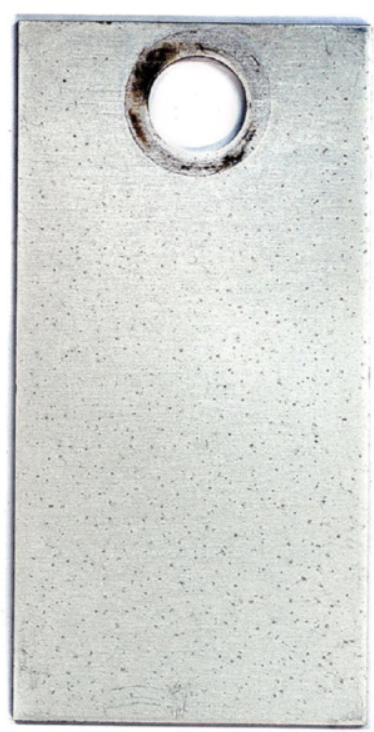

Al- Mg
Fig. 5. Photo of the reverse side of bare aluminium specimens of the four alloys exposed for 2 years at Alicante station. Numerous stains and pits are appreciated on all the alloys, especially on the $\mathrm{Al}-\mathrm{Cu}$ alloy. 


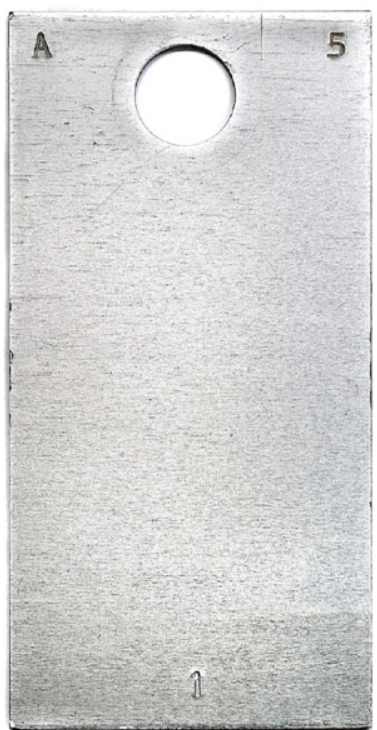

Pure Al

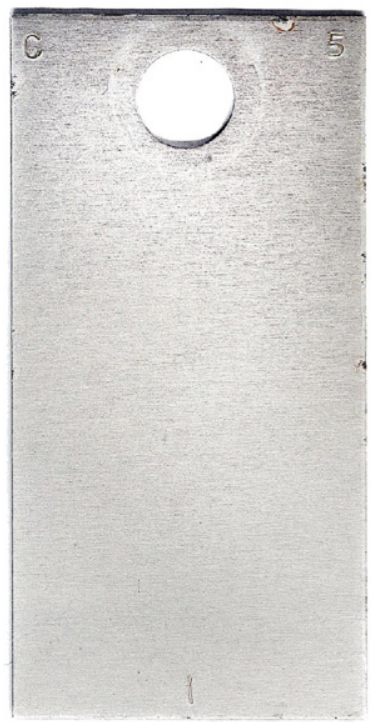

Al-Si-Mg

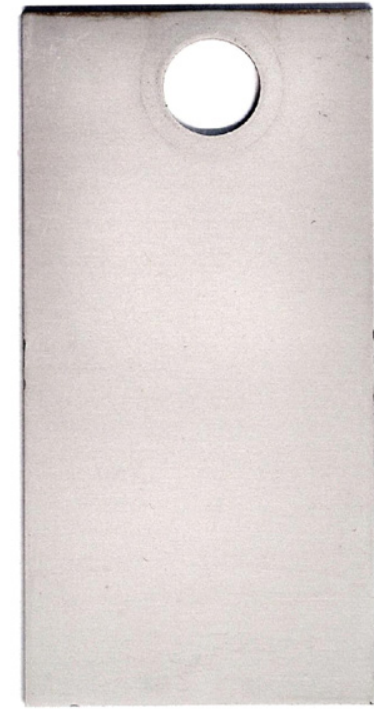

$\mathrm{Al}-\mathrm{Cu}$

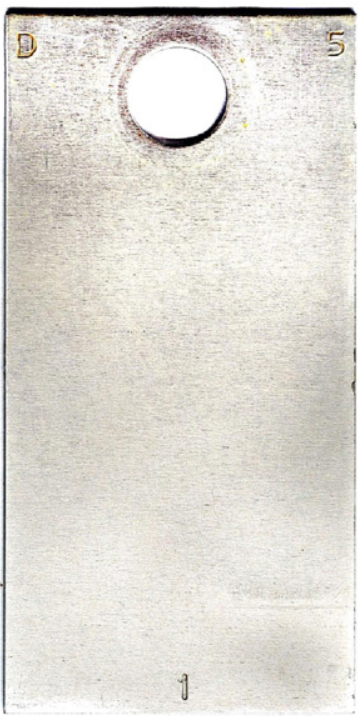

Al- $\mathrm{Mg}$

Fig. 6. Photo of specimens of the four aluminium alloys, anodised with the lowest thickness and sealed, exposed for 2 years at Alicante station. The transparency of the anodic coating allows us to see the appearance of the metallic substrate, but no visible signs of deterioration are appreciated.

which include the corresponding resistance of the solution that fills the opened pores of the unsealed coatings. The authors, with a more complex EC [13] have demonstrated a very satisfactory agreement between experimental and fitted values.

\subsection{Other tests}

Although TEM and SEM have been used extensively during the course of the present project, in this communication only occasional microstructural details obtained by SEM will be noted, using the same methodology described in detail elsewhere [20,32].

Table 5

Visible symptoms of corrosion on bare and sealed anodised aluminium specimens for an exposure time of 24 months at Alicante and Madrid natural test sites

\begin{tabular}{|c|c|c|c|c|c|}
\hline Alloy type & Site & $\begin{array}{l}\text { Bare } \\
\mathrm{Al}\end{array}$ & $\begin{array}{l}7 \mu \mathrm{m} \text { anodic } \\
\text { film }\end{array}$ & $\begin{array}{l}17 \mu \mathrm{m} \text { anodic } \\
\text { film }\end{array}$ & $\begin{array}{l}27 \mu \mathrm{m} \text { anodic } \\
\text { film }\end{array}$ \\
\hline Pure Al & Madrid & ( & O & 0 & 0 \\
\hline $\mathrm{Al}-\mathrm{Si}-\mathrm{Mg}$ & Madrid & ( & 0 & 0 & 0 \\
\hline $\mathrm{Al}-\mathrm{Mg}$ & Madrid & ( & 0 & 0 & 0 \\
\hline Pure Al & Alicante & ○ & O & O & 0 \\
\hline $\mathrm{Al}-\mathrm{Si}-\mathrm{Mg}$ & Alicante & 0 & $\star$ & 0 & 0 \\
\hline $\mathrm{Al}-\mathrm{Mg}$ & Alicante & ○ & 0 & 0 & 0 \\
\hline
\end{tabular}

No signs of local attack.

Spotting on specimen surface.

- Generalised pitting.

$\star$ Pitting only at edges.

Vickers hardness testings were carried out with $0.05 \mathrm{Kg}(\mathrm{HV}$ 0.05 ) on a transversal section of the sample for metallography, using a Wilson Wolpert Mod. 401 MVA microdurometer.

\section{Experimental results}

\subsection{Composition of sealed and unsealed anodic films determined by XPS}

Tables 2 and 3 show the element compositions obtained by XPS on the aluminium alloy surfaces after etching in a soda solution prior to anodising and immediately after the anodising operation. The data are average values for three replicate measurements, and the detection limits for scans developed (20) are $0.1 \%$, approximately. Attention is drawn to the absence in both the passivating and anodic layers of significant amounts of copper, silicon or magnesium, the main alloying elements of $\mathrm{Al}-\mathrm{Cu}, \mathrm{Al}-\mathrm{Si}-\mathrm{Mg}$ and $\mathrm{Al}-\mathrm{Mg}$ alloys, when in the oxides from the thermomechanical obtainment treatment the $\mathrm{Mg} /(\mathrm{Mg}+\mathrm{Al})$ atomic ratios obtained by XPS reach values of the order of 0.20 , practically irrespective of their content in the bulk alloy [28].

\subsection{Information derived from gravimetry at different stages}

Table 4 sets out a series of macroscopic parameters that determine the quality of the anodic films, or at least their quality

Table 6

Visible symptoms of corrosion on bare and unsealed anodised aluminium specimens for an exposure time of 24 months at Alicante and Madrid natural test sites

\begin{tabular}{|c|c|c|c|c|c|}
\hline Alloy type & Site & $\begin{array}{l}\text { Bare } \\
\mathrm{Al}\end{array}$ & $\begin{array}{l}7 \mu \mathrm{m} \text { anodic } \\
\text { film }\end{array}$ & $\begin{array}{l}17 \mu \mathrm{m} \text { anodic } \\
\text { film }\end{array}$ & $\begin{array}{l}27 \mu \mathrm{m} \text { anodic } \\
\text { film }\end{array}$ \\
\hline Pure Al & Madrid & (1) & 0 & O & O \\
\hline $\mathrm{Al}-\mathrm{Si}-\mathrm{Mg}$ & Madrid & (1) & 0 & 0 & 0 \\
\hline $\mathrm{Al}-\mathrm{Mg}$ & Madrid & (1) & 0 & 0 & 0 \\
\hline Pure Al & Alicante & $\bullet$ & O & O & O \\
\hline $\mathrm{Al}-\mathrm{Si}-\mathrm{Mg}$ & Alicante & 0 & $\bullet$ & O & 0 \\
\hline $\mathrm{Al}-\mathrm{Mg}$ & Alicante & 0 & 0 & O & 0 \\
\hline
\end{tabular}

No signs of local attack.

- Generalised pitting.

- Spotting on specimen surface.

- Some isolated pitting. 
(a)

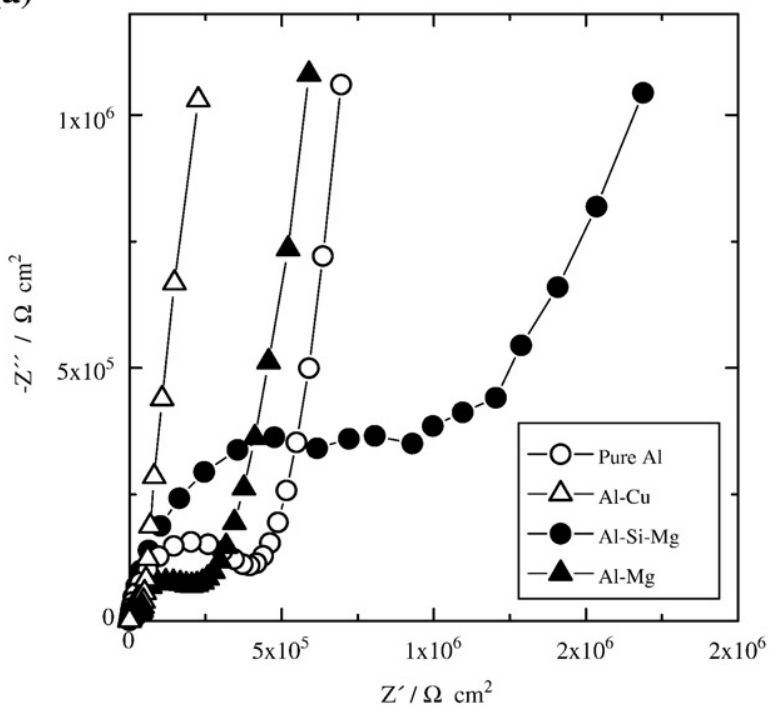

(b)

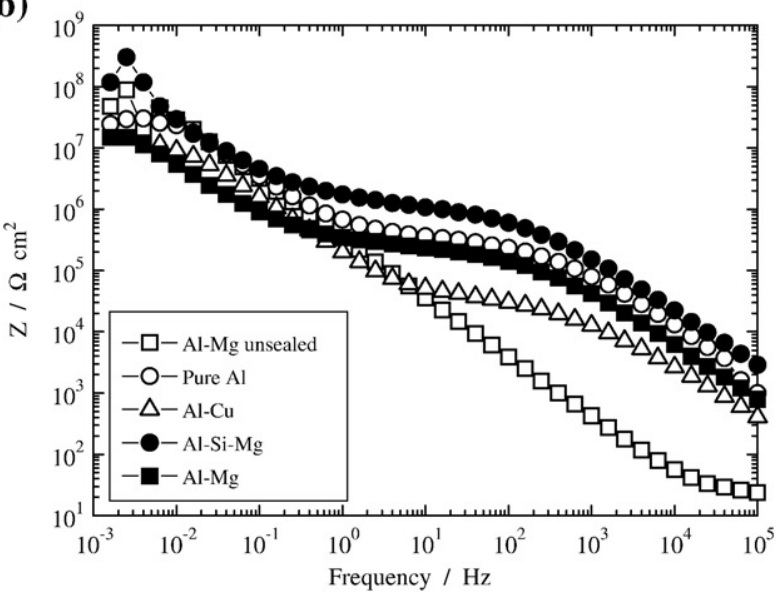

(c)

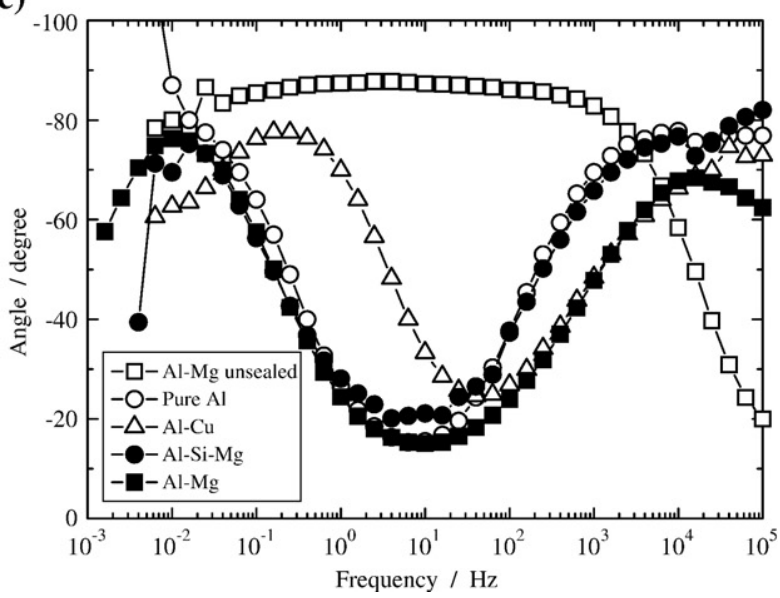

Fig. 7. Impedance diagrams (Nyquist, a) and Bode, b ) and c )) of the anodic films of intermediate thickness recently obtained and sealed. For comparative purposes the diagram corresponding to the unsealed Al-Mg alloy is included.

prior to the sealing process. The temporal cause-effect sequence may be as follows:

(a) The perfection of the passivating layer influences the mass losses during etching in $\mathrm{NaOH}(\Delta \mathrm{m})$ and deter-
Table 7

Data for recently sealed alloys (exposure time 0 months)

\begin{tabular}{lcclcl}
\hline Alloy & $\theta_{\min }\left({ }^{\circ}\right)$ & $\begin{array}{c}R_{\mathrm{p}}\left(\theta_{\min }\right) \\
\mathrm{k} \Omega \mathrm{cm}^{2}\end{array}$ & $\begin{array}{l}C_{\mathrm{b}} \\
\mu \mathrm{F} \mathrm{cm}\end{array}$ & $\begin{array}{l}C_{\mathrm{p}} \\
\mathrm{nF} \mathrm{cm} \mathrm{cm}^{-2}\end{array}$ & $\begin{array}{l}R_{\mathrm{p}}(\text { diam. } \\
\mathrm{k} \Omega \mathrm{cm}^{2}\end{array}$ \\
\hline Pure Al & -15.1 & 432 & 1.04 & 8 & 420 \\
Al-Si-Mg & -20.1 & 1280 & 0.42 & 3.2 & 960 \\
Al-Mg & -29.1 & 251 & 1.80 & 10.2 & 208 \\
Al-Cu & -24.6 & 37 & 0.96 & 71 & 38 \\
\hline
\end{tabular}

mines the perfection of the barrier and porous layers with a mass increase, during anodising, that is greater the more compact the layers.

(b) For the same thickness, smaller mass increases during anodising mean less compact oxide layers, i.e. with greater porosity.

(c) The porosity determines the mass gain during sealing, if this is sufficiently long for the pores to be saturated.

(d) The greater the porosity, the greater the dissolution of the anodic film in the anodising bath, which is proportional to its surface development, since the composition of the unsealed anodic oxides differs little from one alloy to another (Table 3).

(e) A smaller mass increase during anodising, and a greater dissolution of the anodic film in the anodising bath, explains why the anodic oxide formation efficiency decreases progressively from pure aluminium and the $\mathrm{Al}-\mathrm{Si}-\mathrm{Mg}$ alloy to $\mathrm{Al}-\mathrm{Mg}$ and $\mathrm{Al}-\mathrm{Cu}$ (lower coating ratio, $R$ ).

The parameters in Table 4 can be used to establish different correlations, e.g. between porosity and the coating ratio (Fig. 2), defined as the relationship between the amount of oxide formed and the amount of $\mathrm{Al}$ consumed to produce it; or between porosity and attack in the sulphuric solution of the anodising bath (Fig. 3). In general the results suggest a behaviour that indicates an evident connection between these parameters.

The gravimetric data reveals that the moisture captured by the unsealed anodic films of the smallest thickness saturates their pores during atmospheric exposure, leading to autosealing throughout their entire depth on all the considered alloys (Fig. 4a). In contrast, with medium and high thickness films, progressive filling of the pores of unsealed films is detected with exposure time without them becoming completely saturated, since after the two years of exposure the mass gain of the unsealed films is smaller than mass gain during the sealing process, as can be seen in Fig. $4 \mathrm{~b}$ and c. The sealed anodic films experience much smaller changes, since most of the pore volume

Table 8

Data for sealed anodised alloys exposed for 12 months at Madrid natural testing site

\begin{tabular}{lcclcc}
\hline Alloy & $\theta_{\min }\left({ }^{\circ}\right)$ & $\begin{array}{l}R_{\mathrm{p}}\left(\theta_{\text {min }}\right) \\
\mathrm{k} \Omega \mathrm{cm}^{2}\end{array}$ & $\begin{array}{l}C_{\mathrm{b}} \\
\mu \mathrm{F} \mathrm{cm}\end{array}$ & $\begin{array}{l}C_{\mathrm{p}} \\
\mathrm{nF} \mathrm{cm}\end{array}$ & $\begin{array}{l}R_{\mathrm{p}} \text { (diam. } \\
\mathrm{k} \Omega \mathrm{cm}^{2}\end{array}$ \\
\hline Pure Al & -21.5 & 2206 & 0.24 & 3.3 & 1760 \\
Al-Si-Mg & -28.2 & 3530 & 0.48 & 5.6 & 3130 \\
Al-Mg & -19.1 & 890 & 1.80 & 12.5 & 860 \\
Al-Cu & -22.2 & 118 & 0.91 & 59 & 128 \\
\hline
\end{tabular}




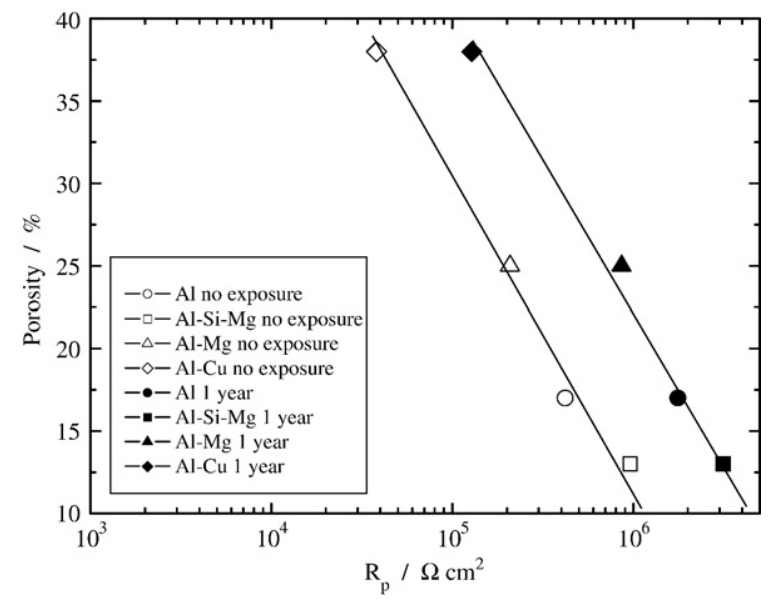

Fig. 8. Effect of porosity and ageing on the porous layer resistance of the anodic films of intermediate thickness developed on the four tested aluminium alloys.

is filled with the water absorbed during sealing, and only a small part is left empty due to the contraction of the gel volume inside the pores during the process of saturation and precipitation after sealing [20]. This empty space usually becomes saturated during the first months of exposure to the atmosphere.

Attention is drawn to the fact that despite the negligible amount of atmospheric corrosion the bare alloys experience evident aesthetic deterioration, above all at the Alicante site (Fig. 5), while anodising, even with the smallest coating thickness, guarantees the conservation of the specimens' appearance (Fig. 6).

Tables 5 and 6 summarise the visual symptoms of corrosion after the longest exposure time considered: 2 years. While the bare specimens show only faint staining at the Madrid site, the typical spotting, those exposed at Alicante are affected by abundant pitting, albeit of a very small depth, so their mechanical properties remain practically unaltered while their appearance is appreciably deteriorated. Anodising, with sealing (Table 5) or without sealing (Table 6), prevents any visual symptom of deterioration with the medium and high thickness coatings, and even with the minimum thickness considered in the Madrid atmosphere. Pitting is only seen in the case of the $\mathrm{Al}-\mathrm{Si}-\mathrm{Mg}$ alloy for the smallest anodic film thickness, at the edges in the case of the sealed specimens and also on the interior of the specimens with the unsealed anodic films. Only a few isolated specimens of the $\mathrm{Al}-\mathrm{Cu}$ alloy were exposed, in view of the deficient quality of the anodic films developed on this material, and the data are not included in Tables 5 or 6 .

\subsection{Characterisation of anodic films by EIS}

Fig. 7 shows impedance diagrams for the four tested aluminium alloys immediately after sealing. The quasi horizontal sections, defined by resistive control due to $R_{\mathrm{p}}$ values, indicates that the porous layer resistance of the $\mathrm{Al}-\mathrm{Cu}$ is one order of magnitude lower than that corresponding to the other alloys (Fig. 7b), to the point that in order to appreciate its $R_{\mathrm{p}}$ it would be necessary to make a new representation on a scale 10 times smaller (Fig. 7a). This impediment is overcome with Bode diagrams, thanks to their logarithmic scale (Fig. $7 \mathrm{~b}$ and c). The described results may be due to the greater porosity of the anodic films developed on $\mathrm{Al}-\mathrm{Cu}$ and may explain the
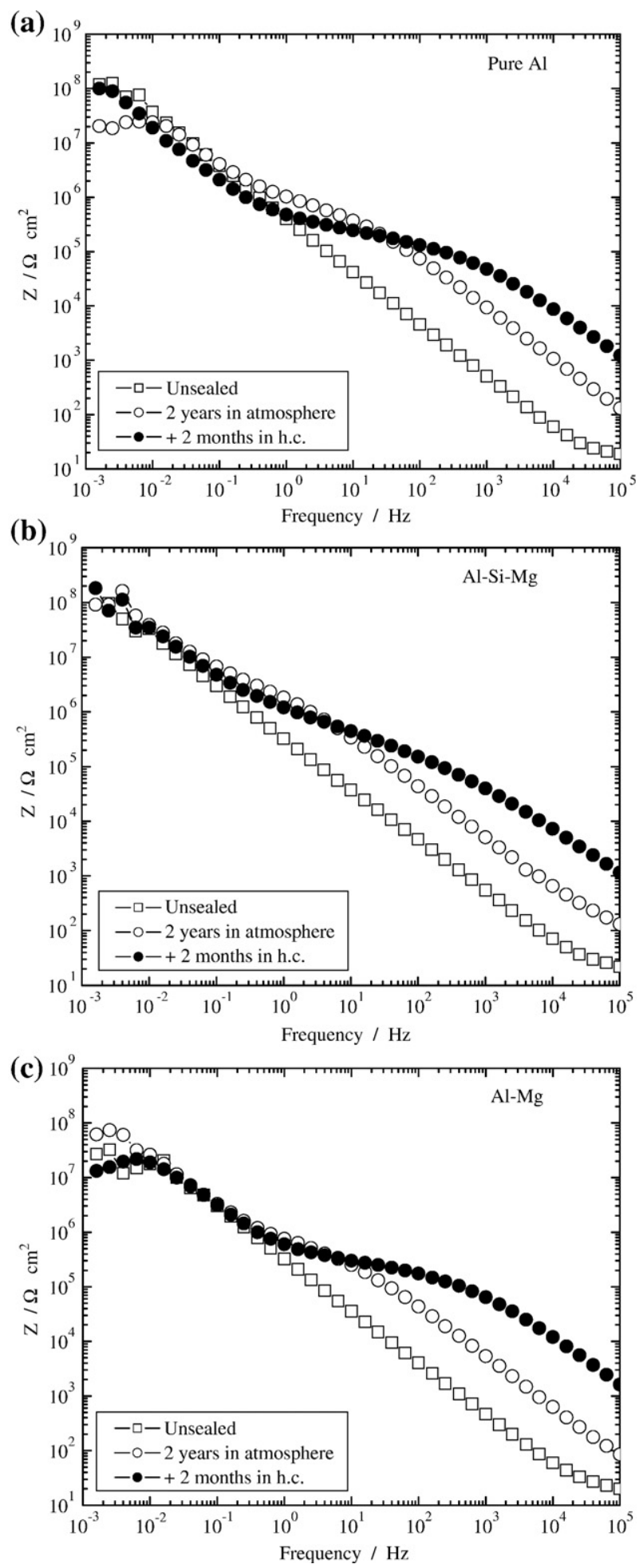

Fig. 9. Comparison between impedance diagrams (Bode) for unsealed anodic films (pores completely empty), partially full after 2 years of exposure at CENIM natural testing station, and saturated in water after 2 additional months in a humidity cabinet. (a) pure $\mathrm{Al}$, (b) $\mathrm{Al}-\mathrm{Si}-\mathrm{Mg}$, and (c) $\mathrm{Al}-\mathrm{Mg}$. 
(a)

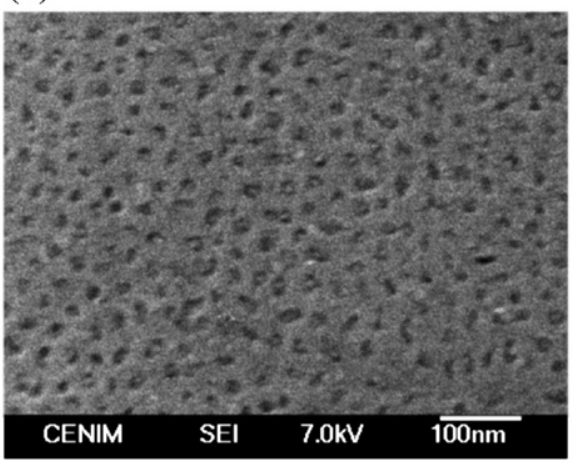

(c)

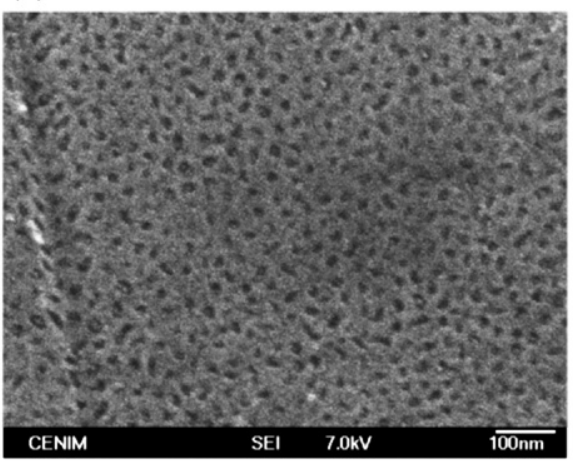

(b)

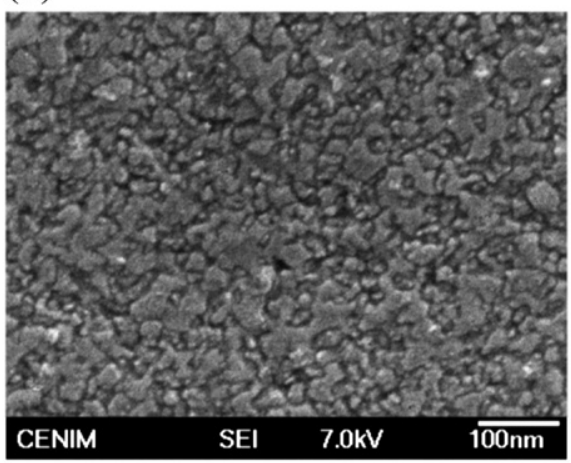

(d)

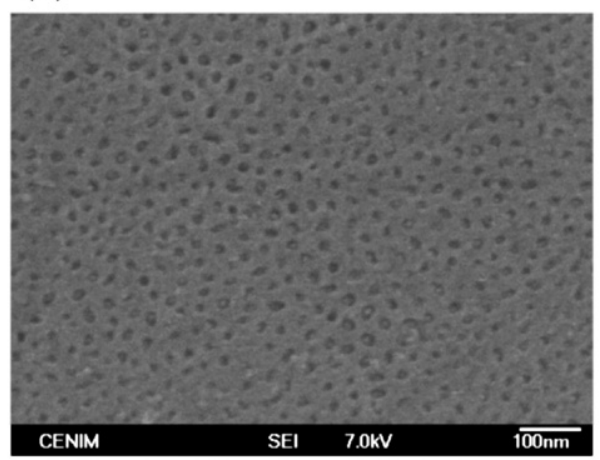

Fig. 10. SEM micrographs of sealed anodic films formed on pure $\mathrm{Al}$ (a); $\mathrm{Al}-\mathrm{Cu}$ (b), $\mathrm{Al}-\mathrm{Mg}$ (c) and $\mathrm{Al}-\mathrm{Si}-\mathrm{Mg}(\mathrm{d})$, alloys.

(a)

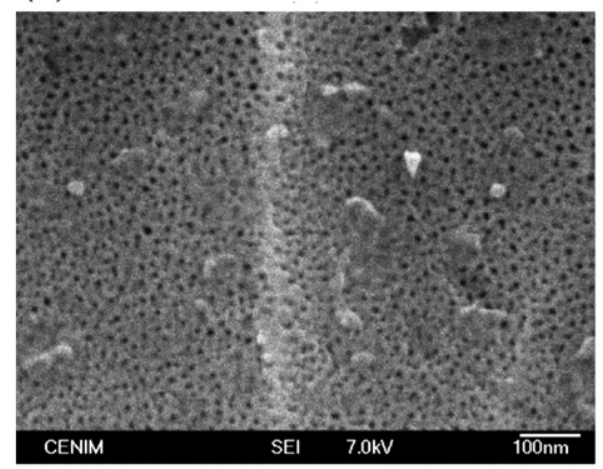

(c)

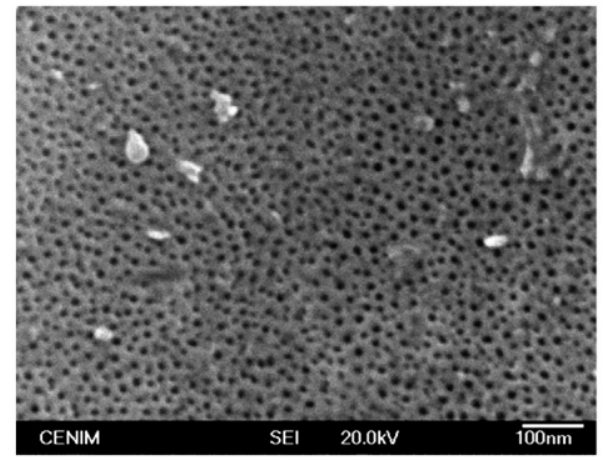

(b)

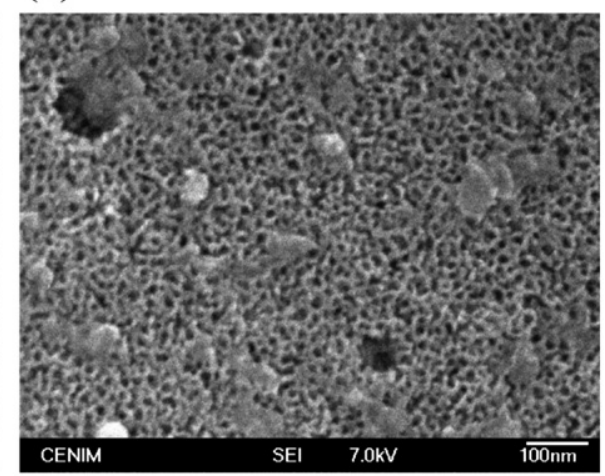

(d)

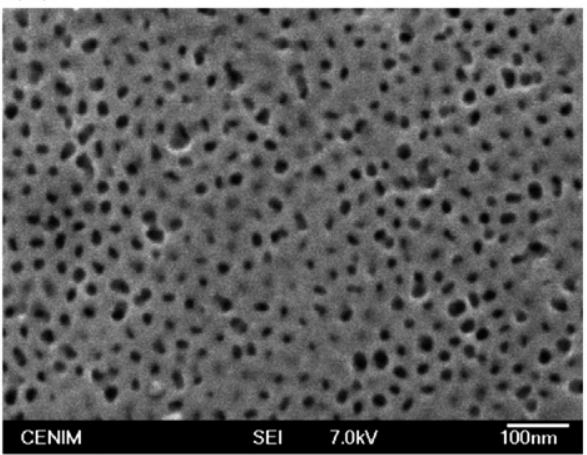

Fig. 11. SEM micrographs of unsealed anodic films formed on pure $\mathrm{Al}(\mathrm{a}) ; \mathrm{Al}-\mathrm{Cu}(\mathrm{b}), \mathrm{Al}-\mathrm{Mg}$ (c) and $\mathrm{Al}-\mathrm{Si}-\mathrm{Mg}$ (d), alloys. 
much lower efficiency of this alloy in the anodising process (parameter $R$ in Table 4). Comparison with the curve corresponding to an unsealed anodic film reveals enormous differences compared to the typical diagrams of sealed oxides.

Impedance diagrams were also determined at the end of the three aforementioned exposure times $-6,12$ and 24 months noting a progressive increase in the $R_{\mathrm{p}}$ with ageing, which according to the literature reveals a progressive improving of the anodic films quality [22,29]. In Tables 7 and 8 , are compared the $R_{\mathrm{p}}, C_{\mathrm{p}}$ and $C_{\mathrm{b}}$ values of recently sealed anodic films and after one year of exposure to the atmosphere, respectively. The values of the different parameters are calculated from the impedance diagrams using the procedures schematised in Fig. 1; although $R_{\mathrm{p}}$ is estimated not only from the $Z$ value corresponding to the minimum phase angle $\theta_{\min }$ (Fig. 1) but also from the diameter of the semicircles defined in the Nyquist diagram (Fig. 7a).

Although the $R_{\mathrm{p}}$ values in Tables 7 and 8 indicate its increase with ageing with all four tested alloys, the graphic representation in Fig. 8 gives an instant quantitative perception of this effect, which is similar for all the materials, and of the clear correlation between the porosity of the anodic films (Table 4) and the resistance or "quality" of the porous layers [22,29], which is greater the lower their porosity. The effect of ageing can very probably vary from one alloy to another and distort the close initial relationship between porosity and $R_{\mathrm{p}}$, but in order to verify this it would be necessary to analyse the changes that take place over much longer time periods.

The evolution with time of the impedance diagrams for unsealed anodic films shows that progressive autosealing takes place, which is very slow due to the long drought experienced in Spain during 2004-2005. However, the autosealing capacity does not disappear with time, it having been found that unsealed specimens exposed for 2 years at the Madrid natural testing site saturate their pores with water if exposed for 2 months in a humidity cabinet and change their impedance diagrams which become similar to those of a high quality sealing (Fig. 9). This type of response, previously seen with $\mathrm{Al}$ of commercial purity $[15,24,33,34]$, continues without significant changes in the case of $\mathrm{Al}-\mathrm{Mg}$ and $\mathrm{Al}-\mathrm{Si}-\mathrm{Mg}$ alloys, as can be seen by comparing the results of Fig. $9 \mathrm{a}$ with $\mathrm{b}$ and $\mathrm{c}$.

\subsection{Other tests}

SEM was used to observe cross sections parallel to the surface plane of the anodic films formed on the different alloys. The results are very similar for pure $\mathrm{Al}, \mathrm{Al}-\mathrm{Mg}$ and $\mathrm{Al}-\mathrm{Si}-\mathrm{Mg}$, revealing a pore network that follows the classic hexagonal distribution, as shown in Fig. 10a, c and d, respectively, for sealed anodic films, and the Fig. 11a, c and d for the unsealed ones. The attempt to anodise the $\mathrm{Al}-\mathrm{Cu}$ alloy results in the formation of oxide layers in which it is impossible to recognise a regular porous structure, as can be seen in Figs. 10b and $11 \mathrm{~b}$. Its appearance looks like a highly disorganized mass with numerous furrows and irregularities.

In the case of the $\mathrm{Al}-\mathrm{Cu}$ alloy the anodic layers are so heterogeneous and discontinuous that their porosity and

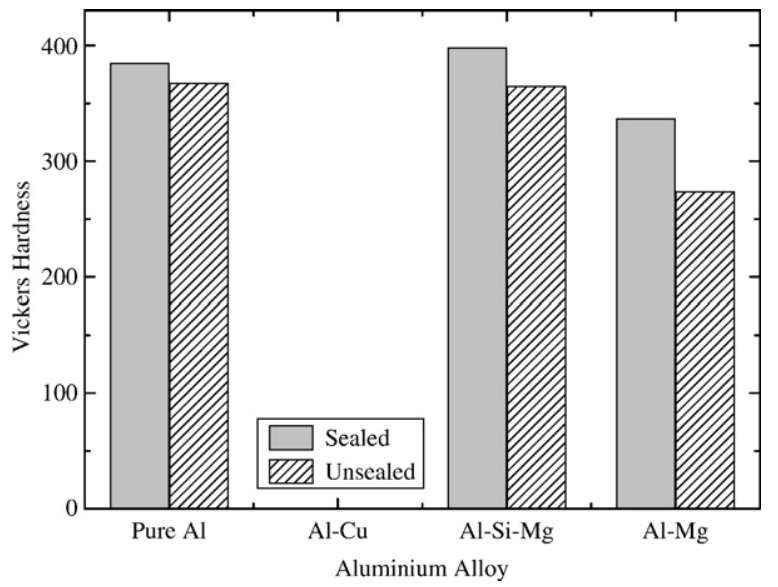

Fig. 12. Hardness of anodic films, of approximately $20 \mu \mathrm{m}$ in thickness, sealed and unsealed, on pure $\mathrm{Al}, \mathrm{Al}-\mathrm{Si}-\mathrm{Mg}$ and $\mathrm{Al}-\mathrm{Mg}$. The anodic films developed on $\mathrm{Al}-\mathrm{Cu}$ were of such poor consistency that it was not possible to determine their hardness.

consistency rapidly degrades as their thickness increases, to the point that it is impossible to measure their hardness (Fig. 12).

\section{Discussion}

\subsection{Chemical composition of surface oxides}

Attention is drawn to the similarity of the composition of the surface oxide layers on all the alloys, with regard to both the passivation layer formed after etching (Table 2) and the anodic films (Table 3). In any case are not detected significant proportions of the main alloying elements, $\mathrm{Mg}, \mathrm{Cu}$ or $\mathrm{Si}$. In the passivating layers the $\mathrm{O} / \mathrm{Al}$ ratio is very close to 1.5 , which means they must essentially be composed of $\mathrm{Al}_{2} \mathrm{O}_{3}$. The $\mathrm{O} / \mathrm{Al}$ ratio is around 2 in the anodic films (Table 3), so the most probable compound is the monohydrate $\mathrm{AlOOH}\left(\mathrm{Al}_{2} \mathrm{O}_{3} \cdot \mathrm{H}_{2} \mathrm{O}\right)$, which highlights the capacity of anodic oxides to react with environmental humidity, at least on their outer surfaces. The participation of $2 \% \mathrm{~S}$ comes from the contamination with the sulphate ion of the anodising bath.

All the signs suggest that the great similarity of the chemical compositions of the anodic films developed on the different alloys would justify similar responses. Thus, the significant differences between the $\mathrm{Al}-\mathrm{Mg}$ and the pure $\mathrm{Al}$ and $\mathrm{Al}-\mathrm{Si}-\mathrm{Mg}$, and the radically different behaviour of $\mathrm{Al}-\mathrm{Cu}$ (Tables 4, 7 and 8; and Figs. 2, 3 and 7), must be due to other causes.

In our opinion, it would be necessary to look for the cause in the microstructural characteristics of the oxides which are built with the same elements and in the same proportions. Fig. 10a and $b$ show totally different microstructures: one regular porous structure with hexagonal cells arranged in a honeycomb pattern (Fig. 10a), described some decades ago as characteristic of anodic films formed on aluminium and its alloys, revealed by SEM on an anodic film formed on pure Al (Fig. 10a) but which is perfectly representative of the anodic films formed on $\mathrm{Al}-\mathrm{Mg}$ (Fig. 10c) and $\mathrm{Al}-\mathrm{Si}-\mathrm{Mg}$ (Fig. 10d). In contrast, the oxide film on the $\mathrm{Al}-\mathrm{Cu}$ alloy (Fig. 10b) shows a highly disorganized 
structure of a granular appearance which corresponds to anodic layers of low thickness. Similar remarks are obtained from the corresponding micrographs of unsealed anodic films (Fig. 11ad). On the $\mathrm{Al}-\mathrm{Cu}$ alloy, as the anodic film thickness grows, the number of defects and the disorder increases, leading to powdery products that crumble at the slightest abrasion, to the point that it is impossible to measure their hardness (Fig. 12).

\subsection{Macroscopic characteristics of anodic films}

The passivating layers formed as a result of etching prior to anodising have a thickness that varies between $2.2 \mu \mathrm{m}$ for pure $\mathrm{Al}$ and the $3.8 \mu \mathrm{m}$ estimated for $\mathrm{Al}-\mathrm{Cu}$ (Table 4). The more defects the passivating films have, the easier the egress of $\mathrm{Al}^{3+}$ ions and the $\mathrm{O}^{2-}$ ions ingress across the pre-existing oxide film, the greater the thickness reached, and the lower its protective power. These imperfections of the passivating oxide are transmitted in some way to the anodic oxides, so that the porosity of the anodic films on pure $\mathrm{Al}$ is practically identical in the case of $\mathrm{Al}-\mathrm{Si}-\mathrm{Mg}$, slightly lower than on $\mathrm{Al}-\mathrm{Mg}$, and only approximately one third of that found on $\mathrm{Al}-\mathrm{Cu}$ (Table 4, Figs. 2 and 3). The porosity derived from the mass gain during the sealing is, in a certain sense, contrary to the "compactness" of the anodic films, reflected in the mass gain associated with anodising (Table 4). The porosity determines the degree of oxide attack in the anodising bath (Fig. 3), so that an additional amount of aluminium is consumed, proportional to the surface development of the oxide, in order to obtain the same anodic film thickness. This means a coating ratio or anodising efficiency so much lower the more greater is the porosity (Table 4 and Fig. 2).

\subsection{Atmospheric exposure}

The insignificant losses of material do not cause any decrease in the mechanical or structural properties of aluminium, even at the Alicante marine site, after two years of exposure. However, in many applications of Al and its alloys, decorative properties are considered to be equally as important as corrosion resistance, and even the slight corrosion that is experienced causes aesthetic effects, as can be seen in Fig. 5, which shows the stains (spotting) developed after two years at the aforementioned site. For exposure times of 2 years or less, the small white stains give way at the Alicante site, but not at the Madrid site, to tiny pits, as shown in Tables 5 and 6, which summarise the visual symptoms that are appreciated on the surface of aluminium, bare and anodised, after exposure. It is underlined that the anodising of aluminium prevents the appearance of local symptoms of deterioration, even for the smallest anodic film thickness (Fig. 6) and on the unsealed coatings. Only on the Al-Si-Mg alloy, with the anodic films of the lowest thickness, tiny isolated pits appear (Tables 5 and 6).

Thus it is correct to state that the anodising of aluminium alloys, above a certain thickness threshold, assures the permanence of the physical characteristics and even the aesthetic appearance of architectural elements exposed to the atmosphere.

\subsection{Anodic film ageing process}

Sealing plugs the mouth of the pores and offers resistance to the passage of current that may be quantified either by the semicircle in Nyquist diagrams (Fig. 7a), by the impedance of the almost horizontal section of Bode diagrams (Fig. 7b) or by the impedance value corresponding to the minimum phase angle (Figs. 1d and 7c). This resistance of recently sealed porous layers $\left(R_{\mathrm{p}}\right)$ is seen to be the highest for the $\mathrm{Al}-\mathrm{Si}-\mathrm{Mg}$ alloy, decreases somewhat for pure $\mathrm{Al}$, is even lower in the case of $\mathrm{Al}-\mathrm{Mg}$, and is approximately one order of magnitude lower for $\mathrm{Al}-\mathrm{Cu}$ (Fig. 7a and b). The greater porosity of the $\mathrm{Al}-\mathrm{Mg}$ anodic films, and above all of $\mathrm{Al}-\mathrm{Cu}$ (Table 4), may be the main cause of the drop in $R_{\mathrm{p}}$, since the pore fill has a much lower resistivity than the hexagonal cell walls. Despite the differences between the alloys, the three straight lines attributed to control by porous layer capacitance $\left(C_{\mathrm{p}}\right)$, porous layer resistance $\left(R_{\mathrm{p}}\right)$, and barrier layer capacitance $\left(C_{\mathrm{b}}\right)$, respectively, are clearly defined in the Bode diagrams in all the cases when shifting from high to low frequencies (Figs. 7b and 9).

In contrast, in the diagrams for the unsealed anodic films only the straight line section imposed by the value of $C_{\mathrm{b}}$ is defined, which is common for pure $\mathrm{Al}, \mathrm{Al}-\mathrm{Mg}$ and $\mathrm{Al}-\mathrm{Si}-\mathrm{Mg}$ (Figs. 7b and 9).

As it happened in the case of commercial purity aluminium [11,17,21-23], the final stage in the complex sealing mechanism, ageing, continues for months and years and finally comes to plug the entire pore length with trihydrated alumina $\mathrm{Al}_{2} \mathrm{O}_{3} \cdot 3 \mathrm{H}_{2} \mathrm{O}-\mathrm{Al}(\mathrm{OH})_{3}-$. These transformations cause a progressive increase in $R_{\mathrm{p}}$, reflected by a shift of the central section in the Bode diagrams towards higher $Z$ values (Fig. 9, Tables 7 and 8 ), which, according to the literature, is equivalent to a progressive improvement in anodic film quality [21,22,30]. This type of behaviour, verified in a wide variety of atmospheres for pure Al anodic films [17,24], is thus repeated with $\mathrm{Al}-\mathrm{Mg}$ and $\mathrm{Al}-\mathrm{Si}-\mathrm{Mg}$, which present entirely comparable ageing processes. Even the defective $\mathrm{Al}-\mathrm{Cu}$ anodic films show a significant increase in $R_{\mathrm{p}}$. However, the $R_{\mathrm{p}}$ values determined for the $\mathrm{Al}-\mathrm{Cu}$ alloy are one order of magnitude lower that those determined for the other alloys (Fig. 8, Tables 7 and 8).

The progressive improving of anodic films also takes place with unsealed films, slowly in atmospheric exposure, to the point that the process has not yet been completed at the end of the 2 years of exposure (Fig. 4), giving rise to intermediate diagrams between an unsealed anodic film and a correctly sealed film (Fig. 9). The autosealing capacity does not disappear with time, it having been seen that unsealed specimens exposed for 2 years at the Madrid natural testing site saturate their pores with water if exposed for 2 months in a humidity cabinet and change their impedance diagrams, from fitting the typical diagrams of incomplete autosealing, with the pores partially plugged, to those characteristic of good quality sealing with the pores completely full. This type of response, already known in the case of commercial purity $\mathrm{Al}[11,17,21-23]$, presents no significant changes in the case of the $\mathrm{Al}-\mathrm{Mg}$ and $\mathrm{Al}-\mathrm{Si}-\mathrm{Mg}$ alloys, as can be seen by comparing the results of Fig. 9a with those of $b$ and $c$. 


\section{Conclusions}

- In atmospheres of low or moderate corrosivity aluminium behaves as a passive material, but the insignificant corrosion that takes place is sufficient to deteriorate its appearance.

- Above an ill-defined thickness threshold, $\leq 17 \mu \mathrm{m}$ according to data, anodising and sealing is an adequate solution for conserving the appearance of aluminium and preventing localised corrosion problems, at least for exposure times of less than 2 years.

- In atmospheric exposure the increase of protective properties of the coating prevails against its deterioration due to corrosion, as in the anodic films developed on pure aluminium and those developed on $\mathrm{Al}-\mathrm{Si}-\mathrm{Mg}$ and $\mathrm{Al}-\mathrm{Mg}$.

- The quality indices of the unsealed anodic films improve with the autosealing-ageing process, faster the greater the environmental relative humidity is, and with a sufficient long time can even exceed industrially established requirements.

- All the parameters that macroscopically define anodic film quality are similar on pure $\mathrm{Al}$ and $\mathrm{Al}-\mathrm{Si}-\mathrm{Mg}$ alloy, somewhat lower on $\mathrm{Al}-\mathrm{Mg}$ and very deficient in the case of the $\mathrm{Al}-\mathrm{Cu}$ alloy anodised in sulphuric acid.

\section{Acknowledgements}

The authors of this work would like to thank to the "Comision Interministerial de Ciencia y Tecnología (CICYT)" for financial support within the framework of project MAT2003-02217.

\section{References}

[1] N.B. Pilling, R.E. Bedworth, J. Inst. Met. 29 (1923) 529.

[2] H.P. Goddard, Mater. perform. 20 (7) (1981) 9.

[3] M. Lashermes, Rev. Alum. (Dec. 1982) 505.

[4] F. Gatto, A. Perrone, Alluminio (Sept. 1981) 434.

[5] E.W. Skerrey, in: W.H. Ailor (Ed.), Atmospheric Corrosion, John Wiley and Sons, New York, 1982, p. 329.

[6] G. Oelsner, Aluminium 54 (1978) 530.

[7] E.A.G. Liddiard, G. Sanderson, J.E. Penn, Trans. Inst. Met. Finish. 49 (1971) 200.

[8] G. Sowinsky, D.O. Sprowls, in: W.H. Ailor (Ed.), Atmospheric Corrosion, John Wiley and Sons, New York, 1982, p. 297.
[9] F.W. Fahy, Br. Corros. J. 18 (1973) 179.

[10] V.E. Carter, J. Inst. Met. 100 (1972) 208.

[11] V. López, J.A. González, A. Bautista, E. Otero, R. Lizarbe, Corros. Sci. 40 (4/5) (1998) 693.

[12] A. Bautista, M. Morcillo, J.A. González, J. Simancas, E. Otero, Rev. Metal. Madrid 34 (3) (1998) 32.

[13] J.A. González, V. López, A. Bautista, E. Otero, X.R. Nóvoa, J. Appl. Electrochem. 29 (1999) 229.

[14] J.A. González, V. López, E. Otero, E. Escudero, Afinidad 62 (519) (2005) 422.

[15] R. Lizarbe, J.A. González, W. López, E. Otero, Aluminium 68 (1992) 140.

[16] J.A. González, M. Morcillo, E. Escudero, V. López, E. Otero, Surf. Coat. Technol. 153 (2002) 225.

[17] V. López, J.A. González, E. Otero, E. Escudero, M. Morcillo, Surf. Coat. Technol. 153 (2002) 235.

[18] V. López, E. Otero, E. Escudero, J.A. González, Surf. Coat. Technol. 154 (2002) 34

[19] J.A. González, S. Feliu Jr., A. Bautista, E. Otero, S. Feliu, J. Appl. Electrochem. 29 (1999) 845.

[20] V. López, M.J. Bartolomé, E. Escudero, E. Otero, J.A. González, J. Electrochem. Soc. 135 (3) (2006) B75.

[21] J.A. González, V. López, E. Otero, A. Bautista, R. Lizarbe, C. Barba, J.L. Baldonedo, Corros. Sci. 39 (6) (1997) 1109.

[22] J.A. González, V. López, E. Otero, A. Bautista, J. Electrochem. Soc. 147 (2000) 984.

[23] V. López, E. Otero, A. Bautista, E. Escudero, J.A. González, Rev. Metal. Madrid, Vol. Extr. (2003) 104.

[24] E. Escudero, Mª.J. Bartolomé, V. López, J. Simancas, J.A. González, M. Morcillo y, E. Otero, Rev. Metal. Madrid 41 (2005) 133.

[25] Standard: ISO 9223, Corrosion of Metals and Alloys. Classification of Corrosivity of Atmospheres, ISO, 1992.

[26] Standard: UNE-EN 12373-2, Aluminio y aleaciones de aluminio. Anodización. Parte 2: Determinación de la masa por unidad de superficie de los recubrimientos anódicos de óxido. Método gravimétrico, 1999.

[27] S. Feliu Jr., M.J. Bartolomé, Surf. Interface Anal. 39 (2007) 304.

[28] S. Feliu Jr., M.J. Bartolomé, J.A. González, S. Feliu, J. Electrochem. Soc. 154 (5) (2007) C241.

[29] T.P. Hoar, G.C. Wood, Electrochim. Acta 7 (1962) 333.

[30] J. Hitzing, K. Juttner, W.J. Lorenz, W. Paatsch, J. Electrochem. Soc. 103 (1986) 887.

[31] J. Hitzing, K. Juttner, W.J. Lorenz, W. Paatsch, Corros. Sci. 24 (1984) 945.

[32] M.J. Bartolomé, V. López, E. Escudero, G. Caruana, J.A. González, Surf. Coat. Technol. 200 (2006) 4530.

[33] E. Escudero, J.A. González, E. Otero, V. López, M. Morcillo, Aluminium 78 (2002) 1006.

[34] E. Escudero, J.A. González, E. Otero, V. López, M. Morcillo, Aluminium 78 (2002) 1094. 